\title{
Monitoring of International Labor Migration in the Context of the World Economy Labor Resources Providing Problems
}

\author{
Svitlana Kalinina \\ Department of Economic and Legal \\ Problems of Urban Studies \\ Institute for Economic and Legal \\ Research \\ Kyiv, Ukraine \\ svit_kalinina@yahoo.com
}

\author{
Lilya Mykhailyshyn \\ Department of Internationa lEconomic \\ Relations \\ Vasyl Stefanyk Precarpathian National \\ University \\ Ivano-Frankivsk, Ukraine \\ kaf_mev@pnu.edu.ua \\ Olga Kushnarenko \\ Department of Economics and \\ International Economic Relations \\ Mariupol State University \\ Mariupol, Ukraine \\ olga-kushnarennko@ukr.net
}

\author{
Yurii Korovchuk \\ Department of International Economic \\ Relations \\ Vasyl Stefanyk Precarpathian National \\ University \\ Ivano-Frankivsk, Ukraine \\ yuriha@ukr.net
}

\begin{abstract}
The article identifies migration as the leading process of labor-intensive provision of the world economy in the current environment. Dynamic and structural indicators of world migration processes are analyzed and generalizations are made on the regularities of their development. The peculiarities of the virtual migration development as a form of the world economy labor supply under conditions of increasing informatization of global socio-economic relations are investigated.
\end{abstract}

Keywords-migration, labor resources, informatization of society, migration policy

\section{INTRODUCTION}

One of the leading factors in global economic development is the labor-intensive provision of the global economy, Whereas country's economy development depends crucially on the state of available labor resources (part of the population that has the physical and intellectual abilities and knowledge to perform useful activities in social production).

The main part of the labor force is the economically active population - that part of the population that has a job and is actively looking for it. The part of economically active population is about $50 \%$ of the world population, $60 \%$ of them are men, $40 \%$ are women [1, p.112].

\section{Modern Migration Processes}

Migration of economically active population is a decisive manifestation of the globalization process, is objective and acts as a leading driver of the of the world economy labor resources provision system, which is facilitated by the fourth industrial revolution and related informatization of the economy, development of multinational corporations, simplification of border crossing, etc. in combination with the aging of the population and the workforce of economically developed countries. [2, p. 3] Globalization fundamentally changes the essence of migration, making the character of modern movements of people latent, and the timing and geographical framework of displacement - unclear, defining the specifics of the world labor market functioning. [3, p.57]

In addition, in the context of globalization, labor migration is becomes one of the tools of professional and social self-realization for workers, expanding the range of possible personalities life strategies aimed at adapting to the present socio-economic realities. [4, p.9] According to the UN, at the beginning of 2018258 million. People. in the world (3.4\% of the world's population) live outside their countries of origin.

Moreover, the increase in the number of migrants shows a stable positive trend: if in 1970 the number of international migrants was 84 million, then in $2000-$ already 173 million people, in 2010 - 220 million people, in $2017-258$ million people (Figure 1). That is, the number of international migrants has tripled compared to 1970.

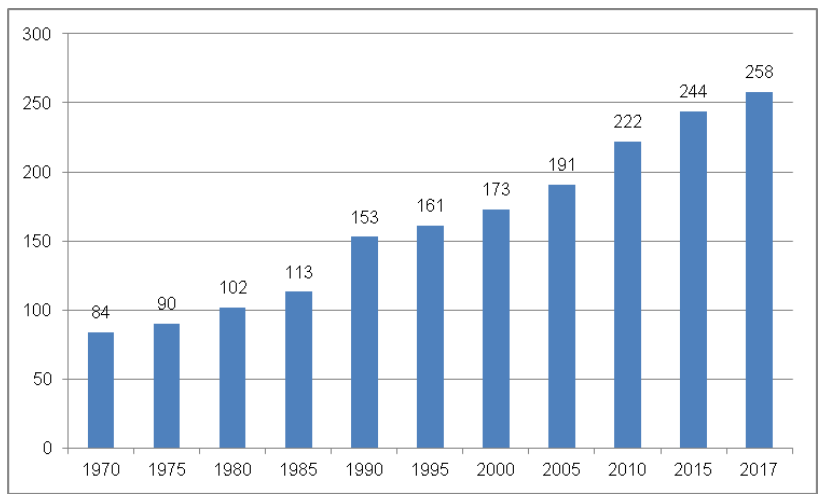

Fig. 1. Dynamics of International Migration in 1970-2017, mln. people [6]

The majority of migrants in 2000-2017, as can be seen from the table 1, accounted for the Asian region, displacement amounted to about 30 million people (with 
an increase of 1.8 million migrants per year), however, the proportion of international migrants in Asia does not generally exceed $2 \%$ of the region's total population (a similar pattern is observed in Africa and Latin America). At the same time, in regions such as Europe, North America and Oceania, the proportion of international migrants is more than $10 \%$ of the total population $[5$, p. 38].

TABLE I. NUMBER OF INTERNATIONAL MIGRANTS BY REGIONS OF THE WORLD IN 2000-2017, MiLlion PEOPLE [5]

\begin{tabular}{|l|c|c|c|c|c|c|}
\hline \multirow{2}{*}{\multicolumn{1}{|c|}{ Region }} & \multicolumn{2}{|c|}{ Rrrived } & \multicolumn{2}{c|}{ Bropped out } & \multicolumn{2}{c|}{ Balance } \\
\cline { 2 - 7 } & $\mathbf{2 0 0 0}$ & $\mathbf{2 0 1 7}$ & $\mathbf{2 0 0 0}$ & $\mathbf{2 0 1 7}$ & $\mathbf{2 0 0 0}$ & $\mathbf{2 0 1 7}$ \\
\hline Asia & 49,2 & 79,6 & 65,0 & 105,7 & $-15,8$ & $-26,7$ \\
\hline Europe & 56,3 & 77,9 & 49,6 & 61,2 & 6,7 & 16,7 \\
\hline North America & 40,4 & 57,7 & 3,2 & 4,4 & 37,2 & 53,3 \\
\hline Africa & 14,8 & 24,7 & 21,6 & 36,3 & $-6,8$ & $-11,6$ \\
\hline $\begin{array}{l}\text { Latin America } \\
\text { the Caribbean }\end{array}$ & 6,6 & 9,5 & 24,8 & 37,7 & $-18,2$ & $-28,2$ \\
\hline Oceania & 5,4 & 8,4 & 1,2 & 1,9 & 4,2 & 6,5 \\
\hline
\end{tabular}

The main component of migration in the modern world is resettlement as a result of economic factors, in which the comparison of quality of life in countries of origin and destination countries is crucial, as evidenced by the distribution of migrants' destination countries by income: in 2017 compared to 2000 the part of high-income countries to which migrants went increased from $58 \%$ to $64 \%$ (Figure 2).
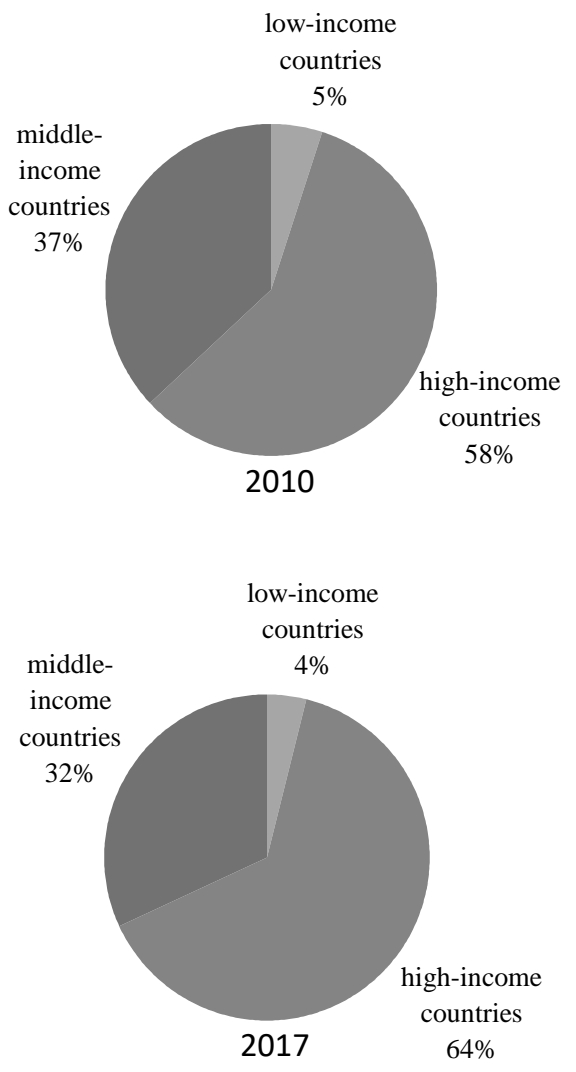

Fig. 2. Distribution of migrant destination countries by income level in 2010 and $2017, \%$ [7]
For migrants and their families, migration can provide significant benefits in terms of income, education and health: according to the UN, moving migrants from the poorest countries to a developed country means for them an increase in income by 15 times, raising the enrollment rate of children by 2 times, reducing infant mortality by 16 times [6].

Migrant workers make up 2/3 of the total number of international migrants, and most of them, as noted, move to high-income countries. Overall, the proportion of developed countries that encourage labor migration increases: if in 1996 only 2\% of countries have taken appropriate action, as of 2017, the proportion of such countries has already been estimated at $25 \%$, and in the whole world the proportion of countries that encourage the involvement of foreign highly skilled labor is approaches $75 \%$ (Table 2).

Thus, the United States, while pursuing a purposeful policy of attracting highly qualified personnel, is a recognized center of gravity for ready professionals. Emigrants who travel to the United States have a greater proportion of scientists and highly qualified specialists than other countries (in particular, 23 members of the National Academy of Sciences of the United States are immigrants). It is estimated that by attracting highly qualified foreign personnel during 1965-2000. US managed to save about $\$ 200$ billion on education and research $[9$, p.55]

Lists of professions in the European Union are being developed, with carriers that can easily obtain a work permit, and create favorable conditions for education for foreign students, holders of highly skilled workforce (who have received a job offer with a wage level exceeding the national average by at least one and a half times) receive a so-called blue card (are exempted from normal employment permit procedures and are granted broad rights in the host country).

And this is quite understandable, because the main factors of economic growth in the conditions of globalization are the intellect, knowledge, competences, which are personified in human, since in the postindustrial model of the world economy the leading role belongs to intellectual labor.

\section{ViRTUAL MigRATION IN THE CONDITIONS OF} LABOR-INTENSIVE PROVISION OF INFORMATION SOCIETY

In addition, virtual migration is widespread in the world economy, which requires workers from one country to execute orders for employers from other countries without actually changing their place of employment and residence, which can significantly reduce the cost of the product (service).

Globalization and the transition to the information society have led to a constant narrowing of the classical employment sphere. In the world labor market, there is flexibilisation and de-standardization of employment, transformation of social-labor relations, accompanied by the emergence of distant relations between employer and employee: according to Illinois Telecommunications Access Corporation (ITAC), in the US in 2015. 21\% of 
employed people accounted for remote employment, $8 \%$ in Europe [4, p.10].

According to the study Top\$dev - Search software services and IT recruiting (29 countries, nearly 170 thousand. developers, more than 1.5 million. Projects) at the beginning of 2017. The order market for IT freelancers from Eastern Europe was shared by the US A (54.5\%), the United Kingdom (10.5\%), Australia (7.0\%), Canada (5.2\%), Germany (3.2\%) (Fig. 3) [10].

table II. Policy Priorities and Strategies for Highly Skilled Migrants [8]

\begin{tabular}{|c|c|c|c|}
\hline Country & Political conditions & Strategies & $\begin{array}{l}\text { Conclusions and } \\
\text { questions that need } \\
\text { consideration }\end{array}$ \\
\hline Kanada & $\begin{array}{l}\text { Migration as an element of the overall development } \\
\text { strategy for professionals with a certain level of skills. } \\
\text { Migration that compensates scarce specialties. }\end{array}$ & $\begin{array}{l}\text { Selection of highly skilled immigrants with } \\
\text { family for permanent residence in the } \\
\text { country. Assistance to international } \\
\text { students. }\end{array}$ & $\begin{array}{l}\text { Goals are generally } \\
\text { achieved. Some problems } \\
\text { with retraining arrived } \\
\text { without an invitation to } \\
\text { work. }\end{array}$ \\
\hline Australia & $\begin{array}{l}\text { Migration as an element of the overall development } \\
\text { strategy for professionals with a certain level of skills. } \\
\text { Migration that compensates for scarce specialties. } \\
\text { Assistance to international students. Goals are } \\
\text { generally achieved. }\end{array}$ & $\begin{array}{l}\text { Selection of highly skilled migrants with } \\
\text { family for permanent residence in the } \\
\text { country. }\end{array}$ & $\begin{array}{l}\text { Some problems } r \text { with } \\
\text { retraining of arrived } \\
\text { persons without an } \\
\text { invitation to work. }\end{array}$ \\
\hline USA & $\begin{array}{l}\text { Protecting local workers when considering employers' } \\
\text { applications for hiring a foreign employee. Preventing } \\
\text { the migration of low-skilled people and limiting } \\
\text { immigration in general. Quotas for the most qualified } \\
\text { categories. }\end{array}$ & $\begin{array}{l}\text { Required invitation to work. An extensive } \\
\text { program for obtaining a temporary } \\
\text { residence permit. A little help for } \\
\text { international students. A huge number of } \\
\text { applicants for existing programs, a big turn. }\end{array}$ & $\begin{array}{l}\text { Return to temporary visas } \\
\text { (exchange, relocation } \\
\text { under the IP program, etc.). }\end{array}$ \\
\hline Great Britain & $\begin{array}{l}\text { Maximum free relocation. Allowing highly qualified } \\
\text { personnel to enter while restricting the migration of } \\
\text { low-skilled people. Rating system for processing } \\
\text { applications for entry from highly skilled migrants, no } \\
\text { quotas. }\end{array}$ & $\begin{array}{l}\text { List of scarce specialties requiring high } \\
\text { qualification. Possibility of entry of foreign } \\
\text { students of scarce specialties. }\end{array}$ & $\begin{array}{l}\text { Goals are generally } \\
\text { achieved. }\end{array}$ \\
\hline France & $\begin{array}{l}\text { Protecting local workers when considering employers' } \\
\text { applications for hiring a foreign employee. Increased } \\
\text { economic migration. }\end{array}$ & $\begin{array}{l}\text { Careful study of the labor market and the } \\
\text { list of professions. }\end{array}$ & Immigration restrictions. \\
\hline Netherlands & $\begin{array}{l}\text { Restriction of migration of people with low skills and } \\
\text { insufficient knowledge of Danish. Exemptions from } \\
\text { the labor market and language exam for migrants with } \\
\text { high levels of skills and wages. }\end{array}$ & $\begin{array}{l}\text { Satisfactory use of high-skilled workers' } \\
\text { entry permits. }\end{array}$ & $\begin{array}{l}\text { Some employers still use } \\
\text { the standard job invitation. }\end{array}$ \\
\hline Germany & $\begin{array}{l}\text { Permission to enter for highly qualified personnel } \\
\text { while restricting the immigration of low-skilled people. } \\
\text { Competition with other countries for highly qualified } \\
\text { staff. }\end{array}$ & $\begin{array}{l}\text { Permanent residence for foreigners with } \\
\text { high qualifications and wages. Hard } \\
\text { restrictions for the rest of the categories. A } \\
\text { number of opportunities for university } \\
\text { graduates. }\end{array}$ & $\begin{array}{l}\text { Immigration restrictions, } \\
\text { ability to change student } \\
\text { status, other. The flow of } \\
\text { migrants does not meet } \\
\text { expectations. }\end{array}$ \\
\hline Norway & $\begin{array}{l}\text { Protecting local workers when considering employers' } \\
\text { applications for hiring a foreign employee. Free } \\
\text { relocation to meet the needs of employers. Required } \\
\text { invitation to work. }\end{array}$ & Quotas for the most qualified categories. & $\begin{array}{l}\text { Existing quotas exceed the } \\
\text { number of applicants. }\end{array}$ \\
\hline Japan & $\begin{array}{l}\text { Admission of highly qualified staff while restricting } \\
\text { the immigration of people with low skills. }\end{array}$ & $\begin{array}{l}\text { Hard delineation of specialties requiring a } \\
\text { high level of skills. Allowing international } \\
\text { students to look for work. }\end{array}$ & $\begin{array}{l}\text { Low migration of highly } \\
\text { skilled personnel, despite } \\
\text { openness. Some students } \\
\text { stay in the country for } \\
\text { work. }\end{array}$ \\
\hline $\begin{array}{l}\text { Czech } \\
\text { Republic }\end{array}$ & $\begin{array}{l}\text { Assistance to Czech employers in the recruitment of } \\
\text { highly qualified foreign employees. }\end{array}$ & $\begin{array}{l}\text { Accelerated acquisition of the right of } \\
\text { permanent residence for highly qualified } \\
\text { foreign workers. }\end{array}$ & $\begin{array}{l}\text { The flow of migrants is } \\
\text { less than expected. }\end{array}$ \\
\hline
\end{tabular}

That is, digital technologies make the labor market truly global, generating a number of benefits of digital employment - non-standard forms of employment, global mobility, decent pay.

The undisputed leaders in the number of freelancers in Europe were Ukraine and the Russian Federation (Figure 4). In 2016 the universities-leaders in terms of IT freelancers training included 3 Ukrainian universities, 1 Russian and 1
Belarusian (Fig. 5), and the leading cities listed in the freelancer profiles were Kyiv, Kharkiv, Zaporizhia, Moscow, Minsk.

It can be stated that under the influence of migration in the highly intelligent segment, the differences in the levels of economic development of the countries are increasing, which deepens the asymmetry of labor resources worldwide. 


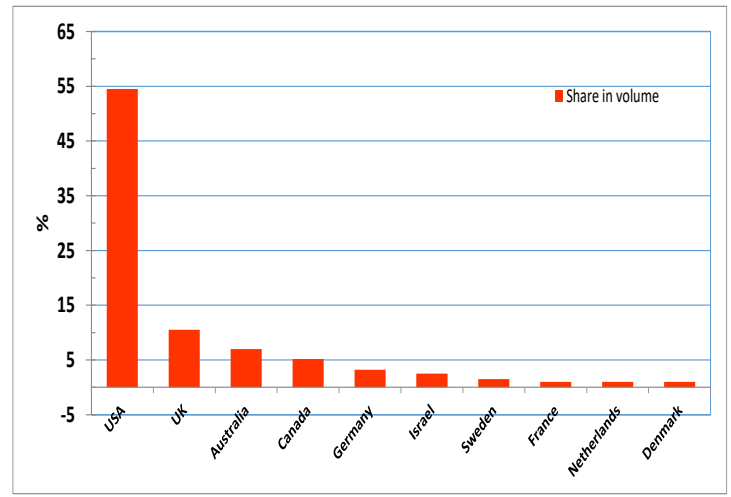

Fig. 3. Eastern European IT Freelancers requesting countries at the beginning $2017, \%$. [10]

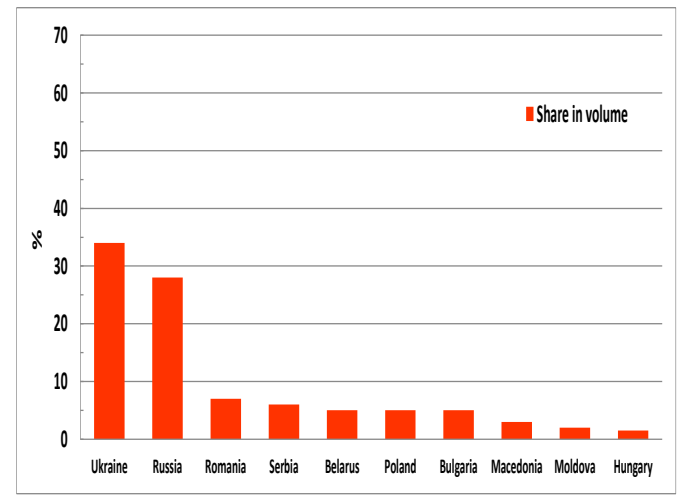

Fig. 4. Leaders in the number of IT freelancers in Europe at the beginning of $2017, \%$ [10]

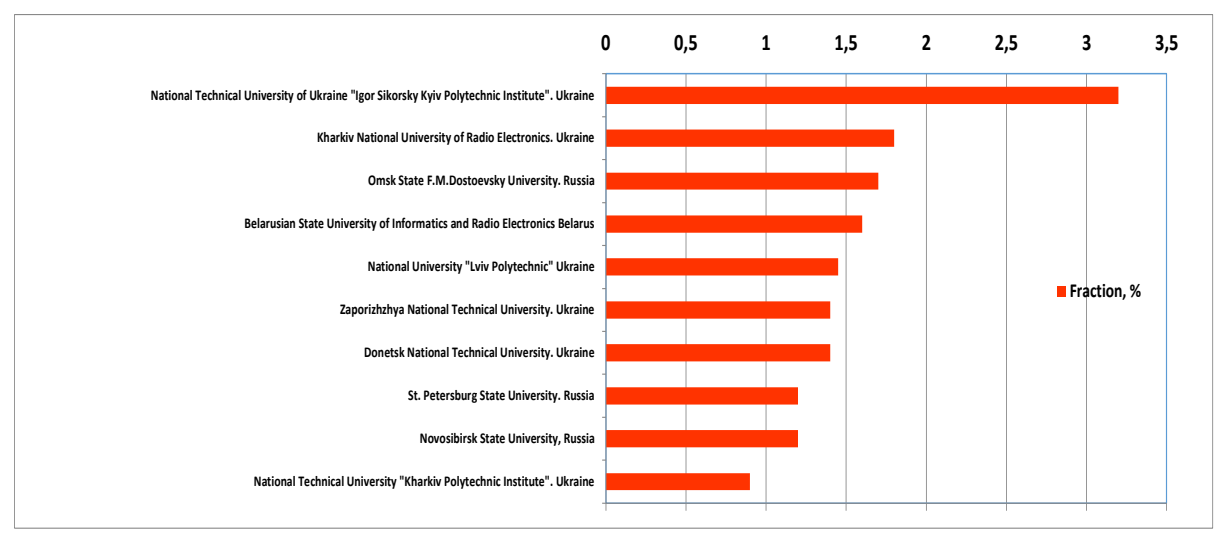

Fig. 5. Universities leaders in Europe in the number of training freelancers in the IT field at the beginning of 2017, \%. [10]

\section{CONCLUSIONS AND GENERALIZATIONS}

The above puts the consideration of labor supply problems in the context of globalization as an urgent task, against the background of rapid changes in the nature of labor, deepening economic and demographic differences between countries, the need to develop the skills required by the labor market.

\section{REFERENCES}

[1] L. S. Shakhovskoy, World Economy and International Economic Relations. Moscou, USA: KNORUS, 2013. [in Ukrainian].

[2] Ukrainian society: a migration dimension. National report. Kyiv, Ukraine: National Academy of Sciences of Ukraine, 2018. [Online]. Available: https://www.idss.org.ua/arhiv/Ukraine_migration.pdf [in Ukrainian]

[3] V. V. Kozar, "The impact of globalization of the world labor market on the efficiency of use of labor potential of Ukraine", International Journal of Innovative Technologies in Economy, № 2 (14), pp. 51-59, 2018. [in Ukrainian].
[4] V. Y. Brich, and M. B. Nagara, Economic analysis and macro and meso levels, Economic Analysis, vol. 25, No. 1, pp. 7-13, 2016. [in Ukrainian].

[5] E. Studny, "Ukrainian students abroad: facts and stereotypes", GEOS, 2017. [Online]. Available: https://cedos.org.ua/uk/articles/ukrainskistudenty-za-kordonom-fakty-ta-stereotypy [in Ukrainian].

[6] In motion. Migration, with all its advantages and disadvantages, is growing worldwide. [Online]. Available: https://www.imf.org/external/russian/pubs/ft/fandd/2018/12/pdf/pictur e.pdf [in Ukrainian].

[7] International Migration Report 2017. Highlights, United Nations, Population Division, 2017

[8] N. I. Patika, O. V. Martinyuk, and D. G. Kucherenko, International Economic News. Kyiv, Ukraine: Center for Educational Literature, 2013. [in Ukrainian].

[9] O. Commandant, "Scientific Center of the International Market for New Economy", News of the Kyiv National University of Taras Shevchenko. Seriya Ekonomika, No. 12 (153), pp. 53-59, 2013. [in Ukrainian].

[10] Eastern Europe IT Freelance Outsourcing Market in 2016. [Online]. Available: http://topsdev.org/blog/obzor-rinka-freelance-2016.htm 